\title{
AKTIVITAS ANTIOKSIDAN EKSTRAK ETANOL DAN n-HEKSANA DARI DAUN RUMPUT SANTA MARIA (Artemisia vulgaris L.) PADA MINYAK IKAN
}

\author{
Erpi Bangol $^{1}$, Lidya I. Momuat ${ }^{1)}$, dan Jemmy Abidjulu ${ }^{1)}$ \\ 1)Jurusan Kimia FMIPA Universitas Sam Ratulangim Manado \\ e-mail: erpi_bangol@yahoo.com; lmomuat@yahoo.com; jemmyabidjulu@yahoo.com
}

\begin{abstract}
ABSTRAK
Penelitian ini bertujuan untuk menentukan kandungan total fenolik dan aktivitas antioksidan ekstrak etanol dan n-heksana dari daun Artemisia vulgaris L. Total fenolik diukur menggunakan metode Follin-Ciocalteau dengan asam galat sebagai larutan standar. Aktivitas antioksidan diukur berdasarkan analisis kadar peroksida dan malonaldehida (MDA) dari minyak ikan. Hasil penelitian menunjukkan bahwa ekstrak etanol memiliki kandungan total fenolik sebesar 81.22 $\mathrm{mg} / \mathrm{kg}$ dan ekstrak n-heksana sebesar $20.10 \mathrm{mg} / \mathrm{kg}$. Kemampuan penghambatan peroksida maupun MDA oleh ekstrak etanol lebih tinggi daripada ekstrak n-heksana. Sebagai pembanding, $\alpha$-tokoferol memiliki aktivitas penghambatan peroksida dan MDA lebih tinggi daripada ekstrak nheksana, tetapi lebih rendah daripada ekstrak etanol.
\end{abstract}

Kata kunci :Artemisia vulgaris L., antioksidan, fenolik, peroksida, malonaldehida

\section{ANTIOXIDANT ACTIVITY OF THE ETHANOL AND n-HEXANE EXTRACTS OF LEAVES OF GRASS SANTA MARIA (Artemisia vulgaris L.) IN FISH OIL}

\begin{abstract}
The purpose of the study was to determine the total phenolic content and antioxidant activity of the ethanol and n-hexane extracts of leaves of Artemisia vulgaris L. Total phenolic was determined using Follin-Ciocalteau method with gallic acid as a standard solution. The antioxidant activity was measured based on the analysis of the levels of peroxide and malonaldehida (MDA) in fish oil. The results showed that the ethanol extract had a total phenolic content of $81.224 \mathrm{mg} / \mathrm{kg}$ and $\mathrm{n}$-hexane extracts of $20.101 \mathrm{mg} / \mathrm{kg}$. The ability of peroxide and MDA inhibition by ethanol extract was higher than that by $n$-hexane extract. For comparison, $\alpha$ tocopherol has higher inhibitory activity on peroxide and MDA than n-hexane extracts, but lower than ethanol extract.
\end{abstract}

Keywords: Artemisia vulgaris L., antioxidants, phenolic, peroxide, malonaldehida

\section{PENDAHULUAN}

Pada umumnya, bahan pangan yang mengandung asam lemak tak-jenuh mudah mengalami kerusakan, salah satunya adalah minyak ikan. Oksidasi asam lemak tak-jenuh yang terkandung dalam minyak ikan merupakan salah satu penyebab utama penurunan mutu minyak ikan selama penyimpanan.

Peroksidasi lipida tidak hanya menjadi masalah dalam industri makanan, tetapi juga dalam tubuh manusia. Pada oksidasi asam lemak tak-jenuh seperti oleat dan linoleat dapat terbentuk hidroperoksida.
Senyawa hidroperoksida mudah terdekomposisi menjadi senyawa volatil berupa aldehida dan asam karboksilat yang menimbulkan aroma tengik pada makanan berlemak. Selain itu, hidroperoksida juga berperan aktif dalam tahapan terjadinya penyakit, seperti jantung koroner. Hidroperoksida asam linoleat menyebabkan kerusakan sel pada lapisan endotelium serta menghambat sintesis prostasiklin pada arteri sehingga mendorong meningkatnya aktivitas platelet yang mengarah ke terjadinya arterosklerosis (Raharjo, 2004). Untuk mencegah terjadinya kerusakan bahan makanan yang mengandung asam lemak tak- 
jenuh dan mengurangi risiko terkena penyakit akibat oksidasi dapat dilakukan dengan menggunakan antioksidan (Shahidi, 1997).

Antioksidan merupakan senyawa kimia yang dapat menghambat reaksi oksidasi. Antioksidan bertindak sebagai penyumbang radikal hidrogen atau bertindak sebagai akseptor radikal bebas (Jadhav et al., 1996). Senyawa antioksidan yang sering digunakan terdiri dari antioksidan sintesis dan antioksidan alami, tetapi antioksidan sintesis diduga dapat menimbulkan efek negatif bagi kesehatan seperti dapat menyebabkan kanker (El Ghany et al., 2010). Karenanya, mendorong berbagai penelitian terhadap sumber antioksidan alami seperti pada tumbuhan obat-obatan, rempah-rempah, sayur-sayuran, dan buah-buahan.

Salah satu tumbuhan yang banyak digunakan karena mengandung zat aktif yang berkhasiat untuk mengatasi penyakit adalah rumput santa maria (Artemisia vulgaris L.). Rumput santa maria telah digunakan untuk mengatasi sakit haid, analgesik, keguguran, diuretika, nyeri ulu hati, disentri, muntah darah, batuk berdahak, keputihan, mimisan dan pendarahan usus (Dalimartha, 2008). Tumbuhan ini juga digunakan dalam terapi akupuntur, mengobati penyakit asma, dan hepatitis (Yoshikawa et al.,1996; Lee et al., 2000). Minyak atsiri daun rumput santa maria memiliki aktivitas antibakteri dan juga mampu menangkal radikal bebas (Silvany, 2013). Sejauh ini, belum diperoleh informasi mengenai aktivitas antioksidan ekstrak etanol dan n-heksana daun Artemisia vulgaris L. pada minyak ikan. Untuk itulah penelitian ini dilakukan dengan tujuan menguji aktivitas antioksidan ekstrak etanol dan n-heksana daun Artemisia vulgaris L. dalam menghambat oksidasi asam lemak tak-jenuh pada minyak ikan.

\section{BAHAN DAN METODE \\ Bahan dan Alat}

Bahan yang digunakan dalam penelitian ini adalah rumput santa maria yang diperoleh dari Desa Pinabetengan, Kabupaten Minahasa, Sulawesi Utara serta minyak hati ikan hiu. Bahan kimia yang digunakan adalah n-heksana, etanol, asam linoleat, reagen Follin-Ciocalteau, natrium karbonat, amonium tosianat $30 \%$, besi(II) klorida 0.02 $\mathrm{M}$, larutan asam klorida $3.5 \%$, asam trikloroasetat (TCA) 20\%, asam tiobarbiturat
(TBA) $1 \%$, larutan buffer fosfat $\mathrm{pH} 7$, asam asetat $50 \%$, air bebas ion, dan $\alpha$-tokoferol serta akuades.

Alat yang digunakan adalah alat-alat gelas, neraca analitik, ayakan 65 mesh, rotary evaporator, vortex, inkubator, alat penangas air, alat penggiling, alat sentrifugasi, dan spektrofotometer UV-Vis.

\section{Preparasi Sampel}

Sampel daun rumput santa maria dibersikan dengan air mengalir, ditiriskan, dikeringanginkan, lalu dipotong kecil dan diblender, kemudian diayak sehingga diperoleh serbuk sampel. Serbuk sampel sebanyak $100 \mathrm{~g}$ masing-masing diekstraksi dengan menggunakan pelarut n-heksana 500 $\mathrm{mL}$ dan etanol (80\%) $500 \mathrm{~mL}$ dengan metode maserasi selama 48 jam pada suhu $5{ }^{\circ} \mathrm{C}$, lalu disaring, kemudian filtrat dievaporasi untuk memisahkan ekstrak dengan pelarut sehingga diperoleh ekstrak kental. Ekstrak hasil evaporasi dikeringkan dalam oven pada suhu $40{ }^{\circ} \mathrm{C}$ selama \pm 48 jam. Selanjutnya masingmasing ekstrak yang diperoleh diuji aktivitas antioksidannya.

Rendemen dari ekstrak daun rumput santa maria dihitung berdasarkan persamaan :

$$
\text { Rendemen }=\frac{\text { Berat ekstrak }}{\text { Berat Sampel }} \times 100 \%
$$

\section{Uji Kandungan Total Fenolik}

Kandungan total fenolik ditentukan dengan menggunakan metode FolinCiocalteau (Conde et al., 1997). Sebanyak 1 mg ekstrak ditambahkan $1 \mathrm{~mL}$ etanol $96 \%$, lalu divortex. Setelah itu, diambil $0,1 \mathrm{~mL}$ larutan ekstrak tersebut dan ditambahkan 0,1 $\mathrm{mL}$ reagen Follin-Ciocalteau 50\%, lalu divortex lagi, kemudian ditambahkan $2 \mathrm{~mL}$ $\mathrm{Na}_{2} \mathrm{CO}_{3} \quad 2 \%$ dan divortex. Selanjutnya campuran tersebut diinkubasi selama 30 menit. Absorbansi sampel dibaca pada panjang gelombang $750 \mathrm{~nm}$. Kandungan total fenolik dari ekstrak dihitung dengan menggunakan kurva standar asam galat.

\section{Analisis Kadar Peroksida dengan Metode Ferric Thiocyanate}

Sebelum pengukuran aktivitas antioksidan, dilakukan inkubasi dan pengukuran absorbansi peroksida larutan blanko. Sebanyak $4 \mathrm{~mL}$ minyak hati ikan hiu $10 \%$ dalam etanol $96 \%$ dan akuades (v/v 1:1, 
yang dilarutkan Carboxy Methyl Cellulose $0.5 \%$ ) ditambahkan $4 \mathrm{~mL}$ buffer fosfat $0,1 \mathrm{M}$ $(\mathrm{pH}$ 7) dan $2 \mathrm{~mL}$ air bebas ion, lalu diletakkan pada wadah gelap tertutup. Campuran tersebut diinkubasi pada suhu 37$40{ }^{\circ} \mathrm{C}$. Analisis kadar peroksida dilakukan 2 hari sekali dengan metode ferric thiocyanate, yaitu $100 \mu \mathrm{L}$ sampel ditambahkan $2,35 \mathrm{~mL}$ etanol $75 \%$ dan $50 \mu \mathrm{L}$ amonium tiosianat $30 \%$. Selanjutnya ditambahkan $50 \mu \mathrm{L} \mathrm{FeCl}_{2}$ $0,02 \mathrm{M}$ dalam $\mathrm{HCl} 3,5 \%$ selama 3 menit, absorbansi diukur pada panjang gelombang $500 \mathrm{~nm}$. Berdasarkan pengukuran absorbansi peroksida blanko tersebut dapat ditentukan lama inkubasi untuk mencapai absorbansi maksimum (misalnya $\mathrm{x}$ hari). Pengamatan absorbansi peroksida sampel daun Artemisia vulgaris L. dilakukan setelah sampel dicampur dengan minyak ikan, lalu diinkubasi. Prosedur yang sama seperti pada blanko, hanya air bebas ion diganti dengan ekstrak sampel (Chen et al., 1996 yang dimodifikasi). Hal yang sama juga dilakukan dengan penambahan $\alpha$-tokoferol. Pada analisis kadar peroksida dan MDA, masingmasing ekstrak sampel maupun $\alpha$-tokoferol dibuat dua konsentrasi, yaitu $100 \mu \mathrm{g} / \mathrm{mL}$ dan $200 \mu \mathrm{g} / \mathrm{mL}$.

\section{Analisis Kadar Malonaldehida (MDA) dengan Metode Thiobarbituric Acid Reactive Substance (TBARS)}

Sebanyak $2 \mathrm{~mL}$ minyak ikan 10\% dalam etanol 96\% dan akuades (v/v 1:1, yang dilarutkan Carboxy Methyl Cellulose 0.5\%) diinkubasi seperti pada analisis kadar peroksida dengan penambahan ekstrak $1 \mathrm{~mL}$ selama $x+2$ hari. Hal yang sama juga dilakukan dengan penambahan $\alpha$-tokoferol. Untuk analisis kadar MDA, sebanyak $1 \mathrm{~mL}$ larutan sampel uji (ektrak etanol dan nheksana, masing-masing $100 \mu \mathrm{g} / \mathrm{mL}$ dan 200 $\mu \mathrm{g} / \mathrm{mL}$ ) ditambahkan $2 \mathrm{~mL}$ larutan asam trikloro asetat (TCA) $20 \%$ dan $2 \mathrm{~mL}$ larutan TBA $1 \%$ dalam pelarut asam asetat 50\%. Campuran ditempatkan pada penangas air yang mendidih selama 10 menit. Setelah didinginkan, disentrifugasi pada $3000 \mathrm{rpm}$ selama 20 menit. Absorbansi supernatan diukur pada panjang gelombang $532 \mathrm{~nm}$ (Kikuzaki dan Nakatani, 1993 yang dimodifikasi). Hal yang sama dilakukan juga untuk kontrol $\alpha$-tokoferol.
Persen penghambatan peroksida atau MDA dihitung dengan rumus:

$\%$ penghambatan $=100-\left(\frac{\text { abs. sampel }}{\text { abs. blanko }} \times 100 \%\right)$

\section{HASIL DAN PEMBAHASAN}

\section{Rendemen Ekstrak Etanol dan n-Heksana Daun Artemisia vulgaris $\mathrm{L}$.}

Daun rumput santa maria yang telah diekstrak dengan pelarut etanol dan nheksana menghasilkan rendemen yang dapat dilihat pada Tabel 1.

Tabel 1. Rendemen ekstrak etanol dan n-heksana daun Artemisia vulgaris L.

\begin{tabular}{|c|c|c|c|}
\hline \multirow[b]{2}{*}{ Sampel } & \multicolumn{2}{|c|}{ Massa (g) } & \multirow[b]{2}{*}{$\begin{array}{c}\text { Rendemen } \\
(\%)\end{array}$} \\
\hline & $\begin{array}{l}\text { Serbuk } \\
\text { sampel }\end{array}$ & $\begin{array}{c}\text { Ekstrak } \\
\text { kering }\end{array}$ & \\
\hline $\begin{array}{c}\text { Ekstrak } \\
\text { Etanol }\end{array}$ & 80 & 4.53 & 5.66 \\
\hline $\begin{array}{c}\text { Ekstrak n- } \\
\text { heksana }\end{array}$ & 80 & 0.98 & 1.22 \\
\hline
\end{tabular}

Pada Tabel 1 rendemen ekstrak etanol lebih tinggi daripada rendemen ekstrak n-heksana. Tingginya rendemen yang diperoleh dari suatu tumbuhan yang diekstrak juga tergantung dengan jenis pelarut yang digunakan untuk mengestrak komponen dari tumbuhan tersebut. Hal ini menunjukkan bahwa komponen yang terkandung dalam daun rumput santa maria lebih banyak terlarut dengan pelarut etanol yang bersifat polar dibanding dengan kelarutan komponen kimia dari daun rumput santa maria dalam pelarut $\mathrm{n}$-heksana yang bersifat nonpolar.

\section{Kandungan Total Fenolik}

Kandungan total fenolik ekstrak etanol dan ekstrak n-heksana dari daun rumput santa maria. tertera pada Gambar 1. 


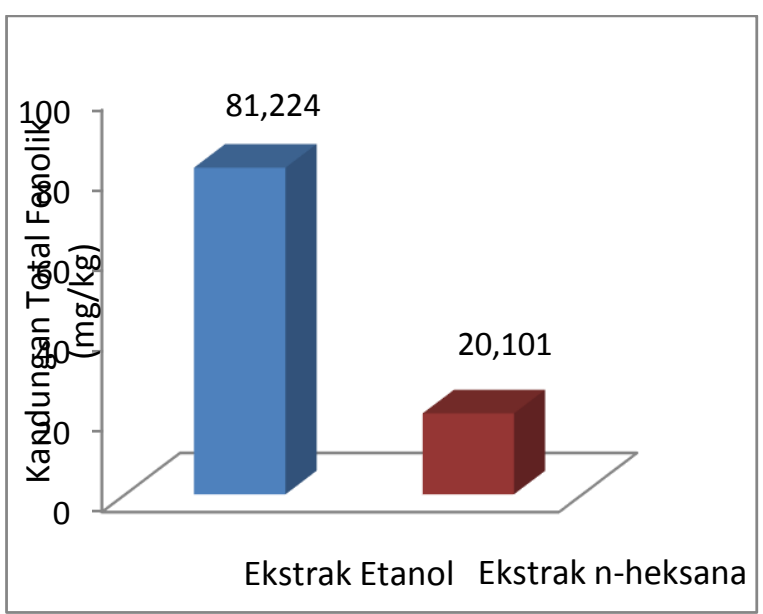

Gambar 1. Kandungan total fenolik dari ekstrak daun rumput santa maria

Ekstrak etanol mempunyai kandungan total fenol yang lebih tinggi daripada ekstrak n-heksana (Gambar 1). Tingginya kandungan fenolik dalam etanol disebabkan oleh sebagian besar senyawa fenolik bersifat polar, yang larut dalam pelarut polar, seperti etanol. Rendahnya kadar total fenol yang terekstrak dengan pelarut n-heksana menunjukkan bahwa ekstrak daun rumput santa maria mempunyai sedikit komponen fenolik dengan kepolaran yang rendah.

\section{Aktivitas Antioksidan Terhadap Penghambatan Peroksida}

Hasil penelitian menunjukkan bahwa nilai absorbansi yang terukur berbanding lurus dengan hidroperoksida yang terbentuk akibat oksidasi asam lemak tak-jenuh. Gambar 2 menunjukkan nilai absorbansi dari peroksida minyak ikan selama inkubasi meningkat sampai hari ke-10, kemudian menurun pada hari ke-12. Inkubasi pada suhu 37-40 ${ }^{\circ} \mathrm{C}$ dimaksudkan untuk mempercepat pembentukan hidroperoksida. Hidroperoksida terbentuk cepat dengan adanya radikal bebas, logam-logam pengkatalis, dan juga faktor cahaya atau panas (Jadvad et al.,1996).

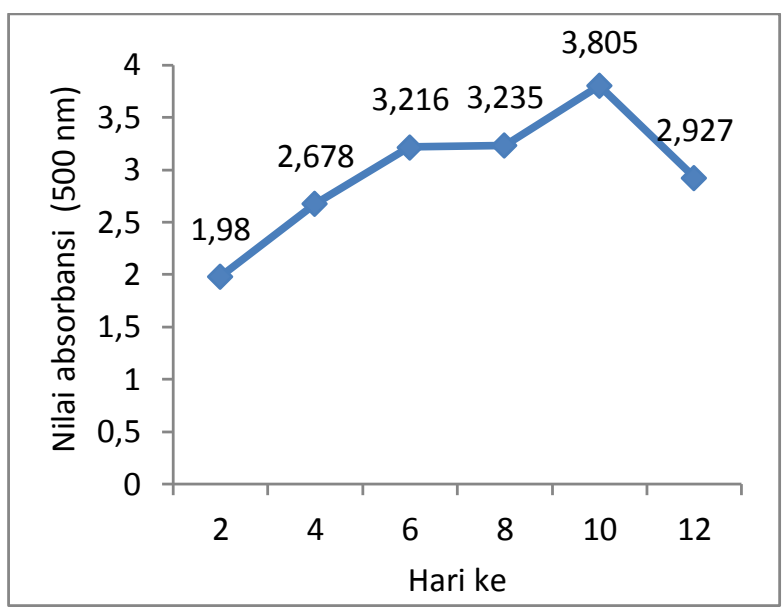

Gambar 2. Nilai absorbansi peroksida (blanko) dari minyak ikan selama inkubasi pada kisaran $37-40{ }^{\circ} \mathrm{C}$

Hasil pengukuran hidroperoksida pada Gambar 2 digunakan untuk menentukan lama inkubasi sampel dan minyak hati ikan, sebelum analisis MDA. Hidroperoksida yang terbentuk akan mengalami dekomposisi, membentuk senyawa antara lain melonaldehida, yang ditunjukkan oleh penurunan absorbansi setelah mencapai absorbansi maksimum. Menurut Kikuzaki dan Nakatani (1993), pengukuran MDA dilakukan setelah satu atau beberapa hari dari puncak absorbansi peroksida. Dalam penelitian ini, absorbansi peroksida maksimum dari minyak ikan terdapat pada hari ke-10 sehingga untuk analasis MDA maka inkubasi dilanjutkan sampai 12 hari.

Santoso et al. (2004) menyebutkan bahwa oksidasi yang terjadi pada emulsi minyak ikan selama proses penyimpanan dapat ditekan oleh aktivitas antioksidan. Adapun aktivitas antioksidan oleh ekstrak daun A. vulgaris $\mathrm{L}$. terhadap oksidasi asam lemak tak-jenuh dalam minyak ikan yang diukur berdasarkan penghambatan peroksida ditunjukkan pada Gambar 3. Ekstrak etanol memiliki aktivitas penghambatan peroksida lebih tinggi daripada ekstrak n-heksana, akan tetapi tidak terlalu berbeda dengan kemampuan penghambatan peroksida oleh $\alpha$ tokoferol. Sedangkan ekstrak n-heksana memiliki aktivitas penghambatan peroksida terendah. 


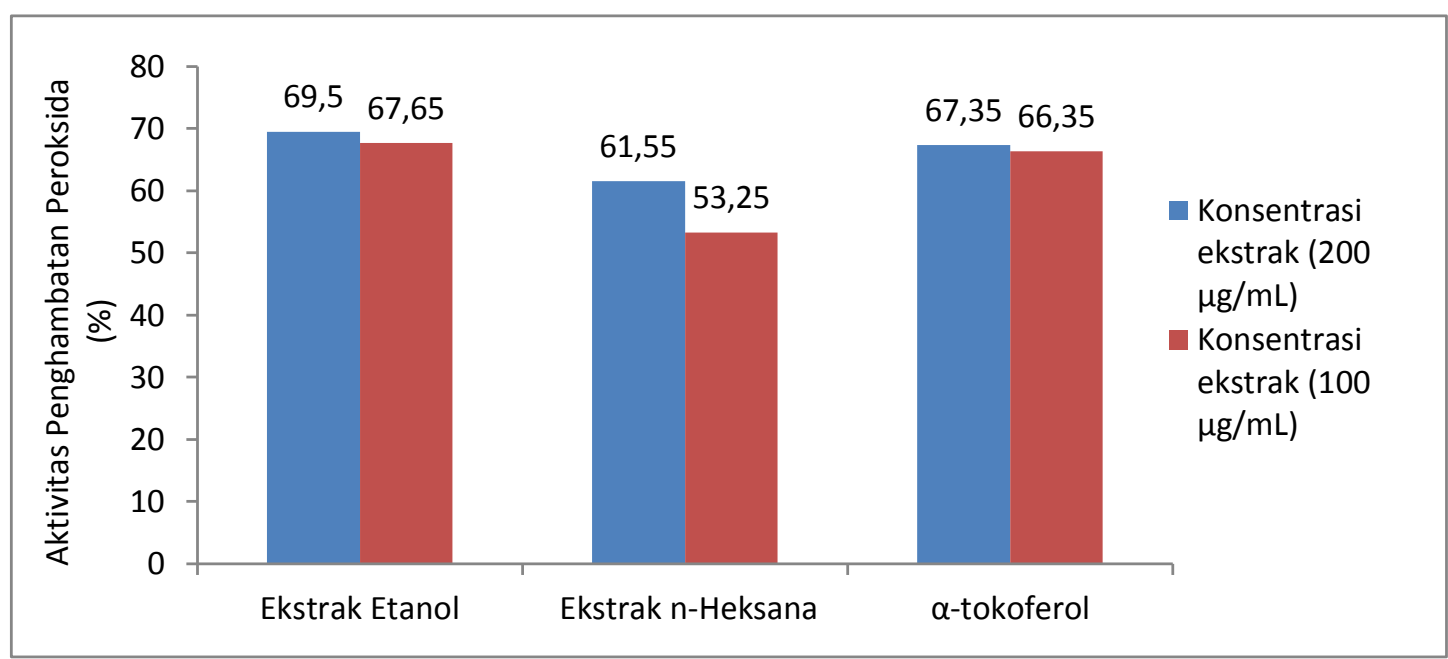

Gambar 3. Penghambatan peroksida oleh ekstrak daun A. vulgaris L. dan $\alpha$-tokoferol sebagai pembanding

Berdasarkan hasil tersebut diketahui bahwa senyawa yang mempunyai aktivitas penghambatan peroksida dalam ekstrak $A$. vulgaris L. merupakan senyawa yang cenderung polar. Hal ini juga sesuai dengan kandungan total fenol yang diperoleh dalam ekstrak A. vulgaris L., yang menunjukkan ekstrak etanol mengandung senyawa fenol lebih tinggi dibanding ekstrak heksannya (Gambar 1). Namun, prosentase aktivitas penghambatan peroksida dari ekstrak etanol dan n-heksana memiliki selisih yang sangat kecil meskipun kandungan total fenolik dari kedua ekstrak tersebut berbeda jauh. Hal ini menunjukkan bahwa pada ekstrak n-heksana mengandung senyawa antioksidan lain yang bersifat non-polar, seperti senyawa-senyawa yang terkandung dalam minyak atsiri Artemisia vulgaris L. yang berpotensi sebagai antioksidan (Silvany , 2013; Judzentiene dan Buzelyte, 2006). Selain itu, komponen yang diduga berkontribusi terhadap ekstrak nheksana adalah klorofil, senyawa klorofil dapat juga berfungsi sebagai antioksidan (Tamat et al., 2007). Ekstrak dengan konsentrasi $200 \mu \mathrm{g} / \mathrm{mL}$ mempunyai kemampuan menghambat peroksida lebih besar dibanding ekstrak dengan konsentrasi $100 \mu \mathrm{g} / \mathrm{mL}$. Pada konsentrasi $200 \mu \mathrm{g} / \mathrm{mL}$, persen penghambatan peroksida berkisar antara $61.55 \%$ sampai $69.50 \%$ dan pada konsentrasi $\quad 100 \quad \mu \mathrm{g} / \mathrm{mL}, \quad$ persen penghambatan berkisar antara $53.25 \%$ sampai $67.65 \%$. Sebagai pembanding, $\alpha$-tokoferol mempunyai kemampuan menghambat peroksida lebih rendah daripada ekstrak etanol, tetapi lebih tinggi daripada ekstrak nheksana.

\section{Aktivitas Antioksidan Terhadap Penghambatan Malonaldehida (MDA)}

$\begin{array}{rlr}\text { Selain } & \text { diukur } & \text { berdasarkan } \\ \text { penghambatan } & \text { peroksida, } & \text { aktivitas }\end{array}$ penghambatan oksidasi pada asam lemak takjenuh juga dapat diukur berdasarkan penghambatan MDA. Malonaldehida merupakan produk sekunder dari oksidasi asam lemak tak-jenuh (hasil dekomposisi peroksida). Aktivitas penghambatan MDA oleh ekstrak A.vulgaris L. dapat dilihat pada Gambar 4 di bawah ini. 


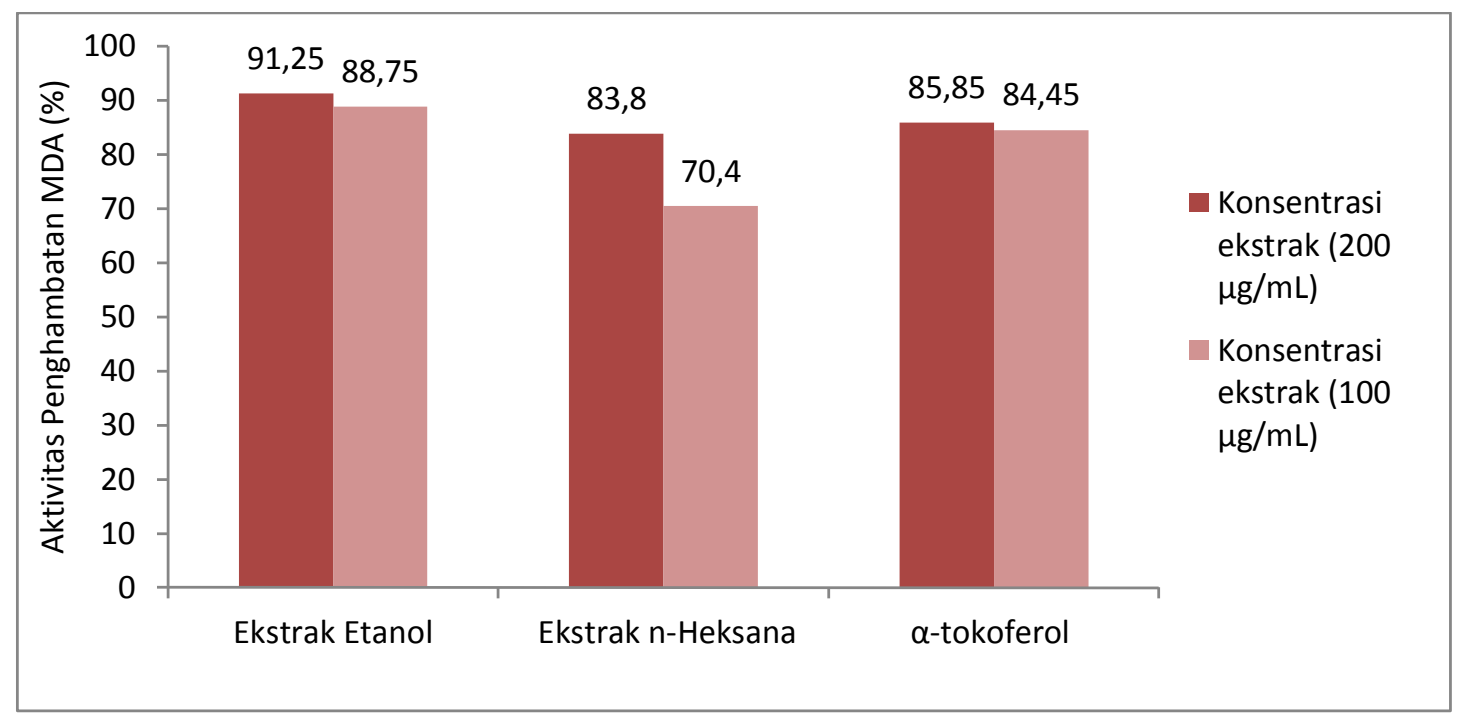

Gambar 4. Penghambatan malonaldehida (MDA) oleh ekstrak daun A. vulgaris L. dan $\alpha$-tokoferol sebagai pembanding

Berdasarkan hasil penelitian (Gambar 4), aktivitas penghambatan MDA oleh ekstrak A. vulgaris L. hasil ekstraksi pelarut etanol adalah yang paling tinggi, yakni sebesar $91.25 \%$ (konsentrasi ekstrak 200 $\mu \mathrm{g} / \mathrm{mL}$ ) dan $88.75 \%$ (konsentrasi 100 $\mu \mathrm{g} / \mathrm{mL})$. Sedangkan ekstrak n-heksana memiliki aktivitas penghambatan MDA yang lebih rendah daripada ekstrak etanol dan juga $\alpha$-tokoferol, yakni $83.80 \%$ (konsentrasi ekstrak $200 \mu \mathrm{g} / \mathrm{mL}$ ) dan $70.40 \%$ (konsentrasi ekstrak $100 \mu \mathrm{g} / \mathrm{mL}$ ). Tingginya aktivitas penghambatan MDA oleh ekstrak etanol daun A.vulgaris $\mathrm{L}$. tergantung pada kemampuan senyawa antioksidan dari ekstrak tersebut dalam menghambat oksidasi. Semakin besar persen penghambatan menunjukkan bahwa semakin besar kemampuan antioksidan dalam mendonorkan hidrogen sehingga asam lemak tak-jenuh dapat terlindungi dari proses oksidasi. Sebagai pembanding, $\alpha$-tokoferol mempunyai aktivitas penghambatan MDA lebih rendah daripada ekstrak etanol, tapi lebih tinggi daripada ekstrak n-heksananya. Pada konsentrasi ekstrak $200 \mu \mathrm{g} / \mathrm{mL}$ memiliki efektivitas antioksidan lebih tinggi daripada konsentrasi $100 \mu \mathrm{g} / \mathrm{mL}$, namun tingginya konsentrasi ekstrak yang diuji tidak selalu seiring dengan tingginya aktivitas antioksidan yang diperoleh karena pada konsentrasi tinggi senyawa fenolik atau antioksidan lainnya dapat berubah menjadi prooksidan (Gordon, 1990).
Hasil penelitian ini menunjukkan bahwa aktivitas penghambatan pembentukan MDA oleh ekstrak daun rumput santa maria, baik ekstrak etanol maupun ekstrak nheksana sinergisme dengan banyaknya senyawa antioksidan yang terekstrak dari masing-masing pelarut. Dengan demikian, dapat diketahui bahwa kemampuannya dalam menghambat oksidasi sebanding dengan senyawa antioksidan yang berperan untuk mendonorkan hidrogen dalam menangkal radikal bebas.

\section{KESIMPULAN}

Kandungan total senyawa fenolik dari ekstrak etanol dan n-heksana daun $A$. vulgaris L. masing-masing adalah 81.224 $\mathrm{mg} / \mathrm{kg}$ dan $20.101 \mathrm{mg} / \mathrm{kg}$. Ekstrak etanol dan n-heksana dari daun $A$. vulgaris $\mathrm{L}$. memiliki aktivitas antioksidan dalam menghambat oksidasi. Ekstrak etanol memiliki aktivitas penghambatan pembentukan peroksida dan MDA lebih tinggi daripada ekstrak nheksannya. Sebagai pembanding, $\alpha$-tokoferol memiliki aktivitas penghambatan peroksida dan MDA lebih rendah daripada ekstrak etanol, tetapi lebih tinggi daripada ekstrak nheksana. 


\section{DAFTAR PUSTAKA}

Chen, H.M., K. Muramoto, F. Yamauchi, and K. Nokihara. 1996. Antioxidant Activity of Designe Peptides Based on the Antioxidative Peptide Isolated from Digests of Soybean Protein. $J$. Agric. Food Chem. 44: 2619-2623.

Conde, E., E. Cadahia, M.C. Gracia, B.F.D. Vallejo, Simion, and J.R.G. Adrados. 1997. Low Moleculer Weight Polyphenol in Cork of Quercus Suber. J. Agric Food Chem.45: 26952700.

Dalimartha, S. 2008. Atlas Tumbuhan Obat Indonesia. Trubus Agriwidya, Jakarta.

El Ghany, M.E., M.S. Ammar, and A.E. Hegazy. 2010. Use of Olive Waste Cake Extract as a Natural Antioxidant for Improving the Stability of Heated Sunflower oil. $J$. World Appl. Sci. 11:106-113.

Gordon M.H. 1990. The mechanism of antioxidant action in vitro. In: B.J.F. Hudson (Ed.), Food Antioxidant. Elservier Applied Science, London and New York.

Jadhav, S.J., S.S. Nimbalkar, A.D. Kulkarni, and D.L. Madhavi. 1996. Lipid Oxidation in Biological and Food Systems. Dalam D.L. Madhavi, S.S. Deshpandeand, D.K. Salunkhe (eds.) Food Antioxidants Technological, Toxicological, and Health, Drespectives. Marcel Dekker, Inc, New York.

Judzentiene, A., and J. Buzelyte. 2006. Chemical Composition of Essential Oil of Artemisia vulgaris L. (mugwort) from North Lithuania. Chemija. 17: 12-15.

Kikuzaki, H., and Nakatani, N. 1993. Antioxidant Effects of Some Ginger Constituents. J. Food Sci. 58: 14071410.

Lee, E., H.Y. Chung, I.K. Lee, S.U. Oh, and I.D. Yoo. 2000. Phenolic with Inhibitory Activity on Mouse Brain Monoamin Oxidase (MAO) from Whole Parts of Artemisia vulgaris. Food Sci. Biotechnol. 9: 179-182.
Raharjo, S. 2004. Oksidasi Lemak pada Makanan: Implikasinya pada Mutu Makanan dan Kesehatan. Universitas Gadjah Mada, Yogyakarta.

Santoso, J., Y. Yoshie-Stark, and T. Suzuki. 2004. AntioxidantActivity of Methanol Extracts from Indonesian Seaweeds in an Oil Emulsion Model. FisheriesScience.70: 183-188.

Shahidi, F. 1997. Natural Antioxidant: Chem. Health Effects and Application. AOCS Press, Champaign, Illinois.

Silvany, R. 2013. Isolasi dan Analisis Komponen Kimia Minyak Atsiri Daun Baru Cina (Artemisia vulgaris L.) serta Uji Aktivitas Antibakteri dan Antioksidan [skripsi]. FMIPA Universitas Sumatra Utara, Medan.

Tamat, S. R., T. Wikanta, dan L. S. Maulina. 2007. Aktivitas Antioksidan dan Toksisitas Senyawa Bioaktif dari Ekstrak Rumput Laut Hijau (Ulva reticulata Forsskal). Jurnal Ilmu Kefarmasian Indonesia. 5: 31-36.

Yoshikawa, M., H. Shimada, H. Matsuda, J. Yamahara, and N. Murakami. 1996. Bioactive Constituents of Chinese Natural Medicines. Chem. Pharm. Bull. 44: 1656-1662. 